\title{
ANALISIS MESIN PENCARIAN GOOGLE SCHOLAR SEBAGAI SUMBER BARU UNTUK KUTIPAN
}

\author{
Ageng Setiani Rafika ${ }^{1}$, Hanafiah Yunan Putri $^{2}$, Fitroh Diah Widiarti ${ }^{3}$ \\ Dosen STMIK Raharja Tangerang ${ }^{1}$, Mahasiswa STMIK Raharja Tangerang ${ }^{2,3}$ \\ Jl. Jendral Sudirman No. 40, Modernland, Tangerang ${ }^{1,2,3}$ \\ email : agengsetianirafika@raharja.info ${ }^{1}$,Hanafiah@raharja.info ${ }^{2}$, fitroh@raharja.info $^{3}$
}

\begin{abstract}
Abstrak
Di era modern seperti saat ini kualitas artikel ilmiah sangat banyak dan beragam jenisnya. Pada tahun 2004 Google memberikan inovasi baru dengan adanya Google Scholar. Google Scholar adalah layanan yang memungkinkan pengguna melakukan pencarian artikel ilmiah atau jurnal berupa teks berbagai format publikasi, salah satunya berupa PDF, yang bertujuan agar pengguna lebih mudah mendapatkan ide atau gagasan untuk membuat karya ilmiah yang berkualitas. Google Scholar bisa menghasilkan artikel ilmiah atau jurnal setiap harinya. Dan setiap artikel ilmiah tersebut terdapat kutipan-kutipan dari orangorang yang membuat artikel tersebut yang bisa pengguna gunakan sebagai referensi dalam pembuatan artikel ilmiah atau jurnal. Metode yang digunakan dalam penelitian ini adalah dengan cara studi pustaka, dimana data yang sudah ada menjadi sebuah informasi yang mudah dipahami dan bermanfaat. Dalam metode SWOT salah satunya memberikan kemudahan bagi pengguna untuk mencari informasi secara cepat dengan hitungan detik di Google Scholar. Penelitian ini juga menggunakan Flowchart dan Prototype yang menunjukkan setiap langkah program atau prosedur dalam urutan yang tepat dan memiliki gambaran dasar saat pengguna menggunakan Google Scholar tersebut.
\end{abstract}

Kata kunci: Google Scholar, Kutipan, Jurnal

\begin{abstract}
In the modern era such as the current quality of the scientific articles are very abundant and diverse. In 2004 Google gives the new innovation with the presence of Google Scholar. Google Scholar is a service that allows users to search for scientific articles or journals in the form of text of various publication formats one of which is a PDF, which aims to let users more easily get the idea or the idea to make a quality scientific work. Google Scholar can produce a scientific article or journal every day. And every scientific article that contained quotes from people who made the article that users could use as a reference in the making of a scientific article or journal. The method used in this research is by literature study, where the existing data into an information that is easily understood and useful. In the method of SWOT one of them provide convenience for users to find information quickly with a matter of seconds in Google Scholar. The research also uses Flowchart and Prototype which shows every step of the program or procedure in the right order and has a basic description when the user uses Google Scholar.
\end{abstract}

Keywords :Google Scholar, Citation, Google Docs

\section{PENDAHULUAN}

Seiring dengan perkembangan zaman yang ada di dunia, Teknologi Informasi (TI) mengalami perkembangan yang sangat pesat.Dengan perkembangan tersebut memberikan dampak positif bagi dunia Teknologi yaitu Internet. Google adalah salah satu perkembangan teknologi mesin pencarian yang sangat diminati atau sering dikunjungi oleh user untuk mencari informasi, dan dengan hitungan detik langsung tampil apa yang user cari. Tahun 2004 Google meluncurkan layanan terbaru yaitu Google Scholar atau 
juga bisa disebut Google Cendekia dalam bahasa indonesia. Google Scholar ini menyediakan layanan seperti informasi yang pastinya bermanfaat berupa PDF (Portable Document Format) secara lengkap dan gratis.Pada umumnya Google Scholar digunakan oleh kalangan pelajar dan mahasiswa untuk mencari referensi dalam membuat karya ilmiah nya.

Di dalam Google Scholar adanyasumber baru yaitu Citations atau kutipan-kutipan dari orangorang hebat dan terpercaya yang bisa langsung tersambung dengan Google Docs ${ }^{[1]}$, dan dengan adanya Google Scholar + Citation jauh lebih mudah, cepat dan praktis, tanpa harus Copy dan Paste. Citation memiliki potensi untuk membantu dalam penulisan karya ilmiah yang sedang di buat dan langsung di kutip ke Footnote di dalam Google Docs.Google Scholar menyajikan kutipan berbagai macam ilmu seperti kesehatan, pengetahuan alam, pengetahuan umum, ekonomi, teknologi, dan lain sebagainya. Secara umum satu universitas di Amerika bisa menghasilkan lebih dari 1.000 jurnal per tahun, dan terdapat 1.000 universitas di seluruh dunia, maka total jurnal yang terbit setiap tahunnya mencapai 1.000.000 jurnal baru . Kutipan adalah gagasan, ide, pendapat yang diambil dari berbagai sumber. Proses pengambilan gagasan itu disebut mengutip.

Di dalam Google Scholar ini memberikan peluang atau kesempatan bagi pemula untuk mengembangkan penelitiannya menjadi suatu karya ilmiah yang berkualitas tinggi. Dan di sini juga menyediakan secara gratis atau free access. Google Scholar sangat mudah di akses dan mudah mendapatkan informasi-informasi yang user cari. Seperti contohnya GS. Peter Jasco telah menerbitkan beberapa karya-karyanya yang sangat kritis dalam Review Information Online (Jasco 2005,2006 a,b) yang membahas karya jurnalnya tentang kekurangan Google Scholar sangat terperinci atau detail, dan pihak google pun sudah ada beberapa yang memperbaiki kekurangan Google Scholar tersebut ${ }^{[4]}$.

\subsection{Permasalahan}

Sebelumnya mahasiswa maupun pelajar masih menggunakan cara Copy dan Paste secara manual di Google Docs dari mouse atau keyboard, mahasiswa dan pelajar pun harus membuka website yang di inginkan lalu memblok kata atau kalimat yang ingin di copy lalu paste ke lembar kerja Google Docs, dan itu pastinya akan membuang-buang waktu. Tapi nyatanya masih banyak yang menggunakan cara manual tersebut dan sudah menjadi tradisi, khususnya bagi mahasiswa atau pelajar di indonesia.

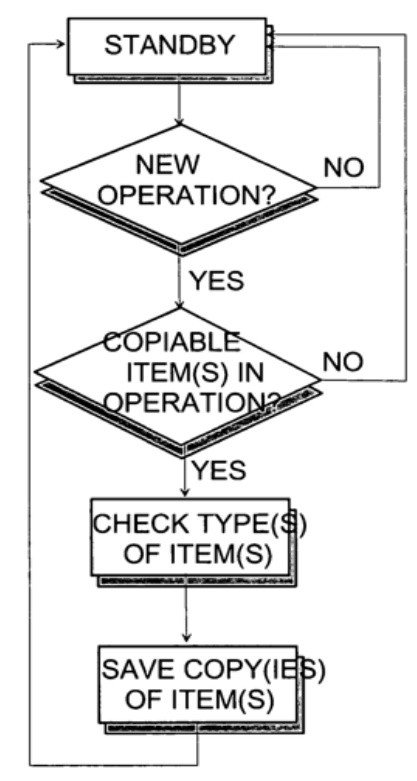

Gambar 1. System Copy

Sumber: Method and system for centralized copy/paste functionality (2005 : Scholar.google.com) 


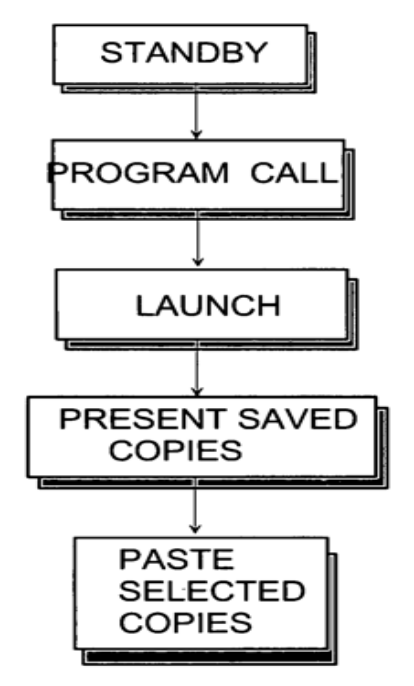

Gambar 2. System Paste

Sumber :Method and system for centralized copy/paste functionality (2005 : Scholar.google.com)

Di tambah lagi jika ingin menambahkan kutipan-kutipan orang, mahasiswa ataupun pelajar harus mengedit terlebih dulu seperti menambahkan kutip dua atas ( "”) dan tahun di publikasi nya kutipan tersebut, pastinya sangat ribet, membuang waktu dan tenaga. Tidak efektif nya cara manual tersebut merugikan mahasiswa ataupun pelajar karena peluang besar terjadi kesalahan ini dan tidak efektifnya kata atau kalimat pastinya akan merugikan penulis dan dengan adanya kesalahan kata karena menggunakan cara manual mengakibatkan mahasiswa ataupun pelajar malas dalam mengerjakan penelitiannya.

Rumusan masalah dalam penelitian ini adalah bagaimana cara mempermudah mahasiswa maupun pelajar untuk Copy dan Paste kata atau kalimat yang ingin di masukan ke dalam penelitian dan bagaimana cara mempersingkat waktu dalam pembuatan catatan kaki atau daftar pustaka pada penelitian yang di buat di dalam Google Docs tanpa ada kesalahan kata atau penulisan narasumber. Tujuan meminimalisir kesalahan kata atau kalimat dalam pembuatan catatan kaki atau daftar pustaka, dan juga sistem kutipan ini mempersingkat waktu mahasiswa dan pelajar dalam pembuatan karya ilmiah terutama dalam pembuatan catatan kaki dan daftar pustaka.Manfaat dari sistem kutipan ini adalah mempermudah dalam pembuatan catatan kaki dan daftar pustaka dan mempercepat dalam pengerjaan catatan kaki dan daftar pustaka.

\section{LANDASAN TEORI}

\subsection{Literature Review}

Literature review adalah bahan yang tertulis berupa buku, jurnal yang membahas tentang topik yang hendak diteliti ([Menurut Hermawan 2009:45]). Banyak sekali penelitian internasional maupun nasional yang membahas tentang Google Scholar sebelumnya. Dalam meneliti tentang Google Scholar dan Citation ini perlu di lakukan studi pustaka sebagai salah satu penerapan metode penelitian yang akan dilakukan. Berikut ini 8 penelitian Internasional dan 2 penelitian Nasional yang telah dilakukan dan memiliki kolerasi yang searah dengan penelitian yang akan dibahas dalam Jurnal ini diantaranya :

1. Penelitian oleh Alireza Noruzi pada tahun 2005 adalah penelitian dengan judul "Google Scholar : The New Generation of Citation Indexes". Pada penelitian ini Google Scholar menyediakan sebuah metode baru mencari terkait artikel tentang suatu subjek dengan mengidentifikasi artikel yang mengutip sebuah kutipan yang sudah disebarluaskan sebelumnya. Studi ini di mulai tentang bagaimana menggunakan Google Scholar untuk menganalisis kutipan dan mengidentifikasi mesin pencarian yang baru ini. Penelitian ini masih di ragukan oleh peneliti karena di bandingkan dengan mesin pencarian yang sudah lama ada jauh lebih lengkap dari pada Google Scholar dan masih di ragukan kebenarannya. Tapi dengan ini pihak Google akan meningkatkan kelengkapan dan keamanan 
Google Scholar nya. Dan bisa disimpulkan bahwa Google Scholar ini menjadi alternatif yang disediakan bebas dan dilengkapi kutipan-kutipan indeks.

2. Penelitian oleh éter Jacsó pada tahun 2005 dengan judul "Google Scholar : The Pros and The Cons". Pada penelitian ini bertujuan untuk mengidentifikasi pro dan kontra pada Google Scholar.Dengan keunggulan nya adalah sangat bermanfaat berkaitan dengan pencarian tentang ilmu seperti contohnya kesehatan. Keunggulan lain nya adalah Google Scholar ini menjadi alat pencarian yang mudah dan gratis, maka memberi kesempatan untuk menjadi calon peneliti di Google Scholar. Ada pula kelemahan di Google Scholar ini adalah jika di Google Scholar ini berkesempatan besar terjadi nya kesalahan pada pencarian yang di inginkan.

3. Penelitian yang dilakukan oleh Isidro F. Aguillo pada tahun 2011 penelitian ini berjudul "Is Google Scholar useful for bibliometrics? A webometric analysis".Google Scholar menjadi alternatif dan suber daya pelengkap oleh kutipan-kutipan di dalamnya untuk database web mesin pencarian ini.Google Scholar ini bukan hanya kutipan-kutipan tetapi juga mencantumkan nama penulis dan lembaga di dalam analisis webometric ini. Sementara ini catatan tentang bibliometrics sudah mencapai 225 Top Level web Domain (TLD). 19,240 universitas dan 6,380 institusi pusat telah dikumpulkan di Google Scholar. Sebagian besar di gunakan berasal dari kalangan pelajar, dengan tugas membuat analisis per individu, universitas yang paling banyak menggunakan Google Scholar ini adalah negara Cina, Brazil, Spanyol, Taiwan dan Indonesia. Dalam beberapa kasus, database Internasional atau nasional bertanggung jawab atas angka tinggi yang ditemukan, namun orang lain termasuk jurnal tampak rendah atau kualitasnya buruk dan laporan tidak di pulikasikan dengan bahanbahan yang tidak jelas asalnya. Google Scholar tidak memiliki kontrol kualitas yang diperlukan untuk digunakan sebagai alat bibliometric, cakupan ini lebih besar yang menyediakan terdiri dalam beberapa kasus item tidak dapat dibandingkan dengan database yang serupa.

4. Penelitian yang dilakukan oleh William H. Walters pada tahun 2006 berjudul "Google Scholar coverage of a multidisciplinary field". This paper evaluates the content of Google Scholar and seven other databases (Academic Search Elite, AgeLine, ArticleFirst, GEOBASE, POPLINE, Social Sciences Abstracts, and Social Sciences Citation Index) within the multidisciplinary subject area of later-life migration. Each database is evaluated with reference to a set of 155 core articles selected in advance the most important studies of later-life migration published from 1990 to 2000. Of the eight databases, Google Scholar indexes the greatest number of core articles (93\%) and provides the most uniform publisher and date coverage.

5. Penelitian yang dilakukan oleh Anne-Wil K. Harzing, Ron van der Wal pada tahun 2008 yang berjudul "Google Scholar as a new source for citation analysis". Traditionally, the most commonly used source of bibliometric data is Thomson ISI Web of Knowledge, in particular the Web of Science and the Journal Citation Reports (JCR), which provide the yearly Journal Impact Factors (JIF). This paper presents an alternative source of data (Google Scholar, GS) as well as 3 alternatives to the JIF to assess journal impact (h-index, g-index and the number of citations per paper). Because of its broader range of data sources, the use of GS generally results in more comprehensive citation coverage in the area of management and international business. The use of GS particularly benefits academics publishing in sources that are not (well) covered in ISI. Among these are books, conference papers, non-US journals, and in general journals in the field of strategy and international business. The 3 alternative GS-based metrics showed strong correlations with the traditional JIF. As such, they provide academics and universities committed to JIFs with a good alternative for journals that are not ISI-indexed. However, we argue that these metrics provide additional advantages over the JIF and that the free availability of GS allows for a democratization of citation analysis as it provides every academic access to citation data regardless of their institution's financial means.

6. Penelitian pada tahun 2010 oleh Joeran Bell, Bella Gipp, Erik Wilde dengan judul "Academic Search Engine Optimization (ASEO): Optimizing Scholarly Literature for Google Scholar \& Co." This article presents the concept of academic search engine optimization (ASEO) to optimize scholarly literature for academic search engines. The first part of the article covers related work that has been done mostly in the field of general search engine optimization for Web pages. The second part defines $A S E O$ and compares it to search engine optimization for Web pages. The third part provides an 
overview of ranking algorithms of academic search engines in general, followed by an overview of Google Scholar's ranking algorithm. Finally, guidelines are provided on how authors can optimize their articles for academic search engines.

7. Penelitian oleh Péter Jacsó tahun 2008 berjudul "Google Scholar Revisited" The purpose of this paper is to revisit Google Scholar. Design/methodology/approach - This paper discusses the strengths and weaknesses of Google Scholar. Findings - The Google Books project has given a massive and valuable boost to the already rich and diverse content of Google Scholar. The downside of the growth is that significant gaps remain for top ranking journals and serials, and the number of duplicate, triplicate and quadruplicate records for the same source documents (which Google Scholar cannot detect reliably) has increased. Originality/value - This paper discusses the strengths and weaknesses of Google Scholar.

8. Penelitian Judit Bar-Ilan tahun 2008 dengan judul penelitian nya adalah "Which h-index? — A comparison of WoS, Scopus and Google Scholar". This paper compares the h-indices of a list of highly-cited israeli researchers based on citation counts retrieved from the Web of Science, Scopus and Google Scholar respectively. In several case the results obtained through google scholar are considerably different from the results based on the Web of Science and Scopus. Data Cleansing is discussed extensively

9. Penelitian Indra Ruslan, Adi Wibowo, Resmana Lim dengan berjudul "Website Penelusuran Artikel Ilmiah Dengan Memanfaatkan Parscit,Google Scholar dan Mendeley API”.pembahasan secara ilmiah yang dilakukan oleh penulis atau peneliti untuk membagikan suatu hal secara logis dan sistematis kepada para pembacanya. Banyak perusahaan besar seperti Google, Mendeley, Endnote, Refworks, Zotero membuat sebuah website untuk menampung semua jurnal yang dipublikasi.Namun setiap website memiliki koleksi dan kapasitas jurnal yang berbeda-beda.Oleh karena itu, pada proyek ini dibuat sebuah website yang berguna untuk mencari koleksi jurnal yang sesuai dengan kebutuhan. Proyek ini dibuat untuk mengefisienkan pencarian jurnal ilmiah yang ada di Mendeley danGoogle Scholar dengan memanfaatkan data paper hasil ekstraksi sitasi ParsCit. Aplikasi website ini dibuat menggunakan Hypertext Preprocessor (PHP) sebagai bahasa pemrograman dan MySQL sebagai database server.

10. Penelitian Noversyah pada tahun tahun 2015 penelitian ini berjudul "Pengukuran Kinerja Layanan Perguruan Tinggi di Era Informasi: Analisis Konten dan Atribut Mutu Website Perguruan Tinggi". Peringkat Perguruan Tinggi (PT) Indonesia berdasarkan lembaga Webometrics dan 4icu relatif tertinggal dibandingkan dengan Singapura, Malaysia, dan Thailand di wilayah ASEAN.Berdasarkan data www.webometrics. Com, jumlah perguruan tinggi Indonesia yang masuk pemeringkatan edisi Juli 2010 adalah sebanyak 140 PT dan 146 PT untuk pemeringkatan 4icu. Pemanfaatan internet, termasuk dengan website resmi, menjadi modal dalam membentuk citra perguruan tinggi yang dapat menjadi faktor pendukung dalam mengatasi persaingan antar perguruan tinggi. Analisis peringkat perguruan tinggi di Indonesia di webometrics merupakan fokus utama pada tulisan ini yang dihubungkan dengan profil atau karakteristik perguruan tinggi nya

Setelah melakukan studi pustaka 10 literature review yang ada, maka dengan adanya penelitian dari orang sebelumnya, yang dibahas dalam literature review ini adalah keunggulan dan kelemahan dari google scholar, hasil dari statistik pengguna google scholar, perbandingan mesin pencarian google scholar dengan mesin pencarian lainnya, kutipan menggunakan $h$-index. Yang akan bahas di dalam jurnal ini adalah memberikan informasi kepada mahasiswa dan pelajar menggunakan cara baru dalam penulisan kutipan dengan cepat, efektif, dan efisien, maka tidak ada lagi kesalahan kata atau kalimat dalam catatan kaki atau daftar pustaka.

\section{HASIL DAN PEMBAHASAN}

Untuk mengatasi masalah ini, maka diperlukan inovasi baru yang efektif dan efisien dalam menulis kutipan pada Footnote dan daftar pustaka. Dengan Google Scholar mempunyai sumber baru yaitu adanyaCitation atau kutipan yang memudahkan mahasiswa maupun pelajar dalam mengerjakan 
penelitiannya dan tidak ribet lagi karena harus membuka Website lalu copy dan paste. Menggunakan cara yang baru ini akan lebih efektif dalam penulisan kutipan pada Footnote maupun daftar pustaka, dikarenakan sistem Citation atau kutipan ini sudah otomatis ada di dalam Footnote yang dikerjakan pada google docs ini. Di dalam Google Scholar + Citation ini mempunyai fasilitas yang lengkap seperti kutipan-kutipan orang yang terkenal maupun kutipan-kutipan orang terpercaya yang pastinya mudah di akses dan gratis.Citation ini memang di khususkan untuk kalangan pelajar, mahasiswa maupun orangorang yang ingin memulai penelitian. Dalam pemecahan masalah ini menggunakan mind mapping dan analisis SWOT:

\subsection{Mind Mapping}

Mind mapping adalah cara mengembangkan kegiatan berpikir ke segala arah, menangkap berbagai pikiran dalam berbagai sudut. Mind mapping mengembangkan cara berpikir divergen dan berpikir kreatif. Mind mapping yang sering kita sebut dengan peta konsep adalah alat berpikir organisasional yang sangat hebat yang juga merupakan cara termudah untuk menempatkan informasi ke dalam otak dan mengambil informasi itu ketika dibutuhkan ([Tony Buzan , 2008:4]).

Dilihat dari tujuan dari kutipan ini adalah meminimalisir kesalahan kata atau kalimat dan memudahkan mahasiswa atau pelajar membuat catatan kaki dan daftar pustaka. Tujuan ini pastinya akan ada manfaat bagi mahasiswa dan pelajar untuk mempercepat kerja dan mempermudah dalam penulisan catatan kaki maupun daftar pustaka. Keuntungan dalam kutipan ini adalah otomatis terkutip di google docs tepatnya otomatis tertulis di catatan kaki atau Footnote maka mempermudah bagi mahasiswa maupun pelajar, cepat dalam pencarian kutipan-kutipan dan mahasiswa dan pelajar tidak perlu lagi repot membuka website atau file-file kalimat yang ingin di kutip. Dalam sistem kutipan ini bisa digunakan oleh semua user yang tersambung dengan internet, tetapi dengan kelebihan-kelebihan tersebut kutipan juga masih memiliki kekurangan yaitu belum efisien dalam pencarian kutipan masih banyak yang belum ada di google scholar, dan sistem kutipan ini hanya bisa di google docs karena kutipan ini dibuat oleh Google. Lima poin mind mapping tersebut diambil berdasarkan fakta yang sudah ada di penelitian sebelumnya oleh peneliti.

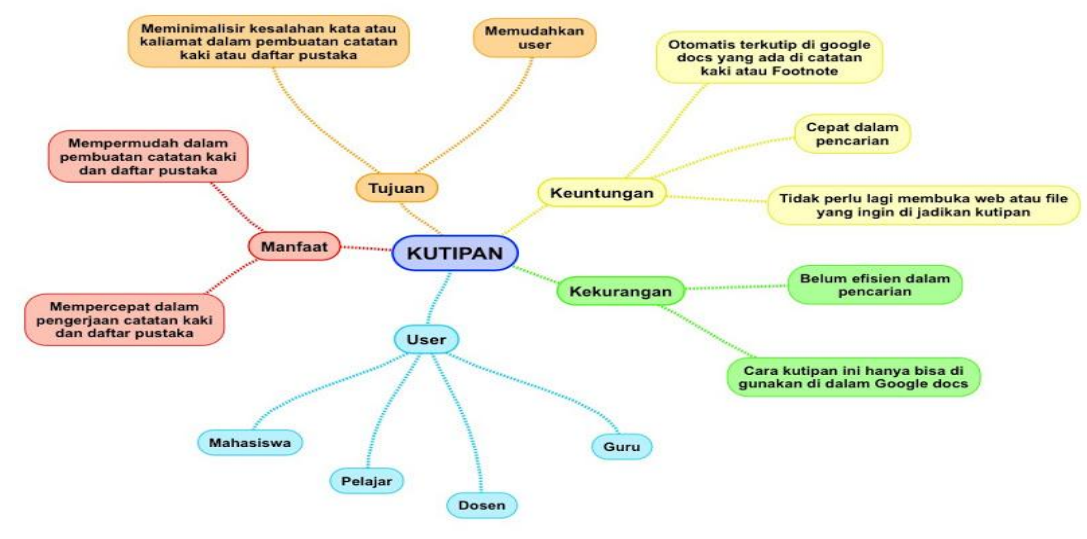

Gambar 3. Mindmap kutipan

\subsection{SWOT}

SWOT digunakan untuk menilai kekuatan-kekuatan dan kelemahan-kelemahan dari sumbersumber daya yang dimiliki perusahaan dan kesempatan-kesempatan eksternal dan tantangan-tantangan yang dihadapi ([Jogiyanto 2005]). Pada permasalahan ini menggunakan metode SWOT yang dapat dijelaskan langkah-langkah sebagai berikut : 
Tabel 1. Analisa SWOT

\begin{tabular}{|c|c|c|}
\hline Faktor Internal & $\begin{array}{c}\text { Strenght } \\
\text { (Kekuatan) }\end{array}$ & $\begin{array}{c}\text { Weakness } \\
\text { (Kelemahan) }\end{array}$ \\
\hline Faktor Eksternal & $\begin{array}{l}\text { 1. Mudah di akses karena } \\
\text { terhubung dengan } \\
\text { Google scholar } \\
\text { 2. Prosesnya cepat } \\
\text { 3. Memudahkan dalam } \\
\text { pembuatan kutipan di } \\
\text { dalam Google docs } \\
\text { 4. Banyak sekali kutipan- } \\
\text { kutipan orang } \\
\text { terpercaya } \\
\text { 5. Free access }\end{array}$ & $\begin{array}{l}\text { 1. Masih di ragukan } \\
\text { kebenarannya } \\
\text { 2. Hanya bisa dilakukan di } \\
\text { Google docs }\end{array}$ \\
\hline Opportunity (Peluang) & Strategy SO & Strategy WO \\
\hline $\begin{array}{l}\text { 1. Mesin pencarian } \\
\text { semakin di minati bagi } \\
\text { pelajar maupun } \\
\text { mahasiswa } \\
\text { 2. Semakin banyak yang } \\
\text { menggunakan Google } \\
\text { docs dan menggunakan } \\
\text { kutipan atau Citation }\end{array}$ & $\begin{array}{l}\text { 1. Memberikan kemudahan } \\
\text { untuk mahasiswa dan } \\
\text { pelajar dalam } \\
\text { mengerjakan catatan } \\
\text { kaki atau daftar pustaka } \\
\text { 2. Keefektifan dalam } \\
\text { membuat kutipan } \\
\text { 3. Cepat dalam mencari } \\
\text { informasi di Google } \\
\text { Scholar }\end{array}$ & $\begin{array}{l}\text { 1. Mengajarkan kepada } \\
\text { mahasiswa maupun } \\
\text { pelajar dengan } \\
\text { menggunakan cara } \\
\text { kutipan di dalam Google } \\
\text { Docs }\end{array}$ \\
\hline Threat (Ancaman) & Strategy ST & Strategy WT \\
\hline $\begin{array}{l}\text { 1. Semakin banyak inovasi } \\
\text { baru mesin pencarian } \\
\text { yang lebih lengkap dan } \\
\text { mudah. } \\
\text { 2. Adanya mesin pencarian } \\
\text { yang berbasis offline } \\
\text { lengkap dan cepat. }\end{array}$ & $\begin{array}{l}\text { Memperkenalkan cara } \\
\text { cepat menggunakan } \\
\text { kutipan di Google docs } \\
\text { dalam membuat catatan } \\
\text { kaki atau daftar pustaka }\end{array}$ & $\begin{array}{l}\text { 1. Mencari kutipan-kutipan } \\
\text { yang bermutu atau } \\
\text { berkualitas }\end{array}$ \\
\hline
\end{tabular}

Faktor internal maupun faktor eksternal setelah di bandingkan keduanya memiliki Strategi yang pertama adalah Strategi SO (Strenght, Opportunity) yaitu dengan memberikan peluang kemudahan untuk mahasiswa ataupun pelajar untuk mempercepat kerja nya dalam membuat catatan kaki dan daftar pustaka.Terjaminnya keefektifan kata atau kalimat mendapatkan nilai plus dalam penulisan karya ilmiah.Dengan tujuan mempermudah dan mempercepat dalam penulisan catatan kaki atau daftar pustaka sistem kutipan di Google scholarini juga banyak file-file berbentuk PDF yang pastinya lengkap dengan hitungan detik langsung tampilkan. Kedua adalah Strategi ST (Strenght, Threat) yaitu setelah dibandingkan strategi ini memperkecil mahasiswa atau pelajar kebiasaan dalam menggunakan cara lama copy,paste dengan cara baru dalam Google docs. Ketiga adalah Strategi WO (Weakness, Opportunity) yaitu mengajarkan kepada mahasiswa dan pelajar bagaimana cara menggunakan kutipan di google scholar karena masih banyak yang belum mengetahui cara pemakaian kutipan di google docs secara otomatis. Dan strategi yang terakhir adalah Strategi WT (Weakness, Threat) yaitu mahasiswa dan pelajar harus mencari kutipan-kutipan yang bermutu dan berkualitas karena di dalam google scholar ini masih adanya pencarian yang tidak sesuai dengan apa yang user cari.

\subsection{Flowchart Rancangan Aplikasi}

Flowchart adalah penggambaran secara grafik dari langkah-langkah dan urut-urutan prosedur dari suatu program ([Menurut Adelia 2011:116]).. Berikut flowchart sistem kutipan di dalam google docs sebagai berikut :

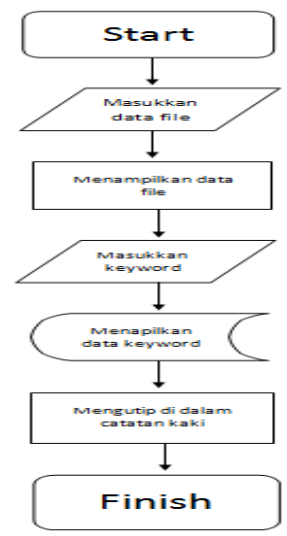

Gambar 4. Flowchart Sistem Kutipan pada Google Docs 
Dari flowchart di atas dijabarkan bahwa hal yang pertama dilakukan oleh mahasiswa dan pelajar adalah membuka atau memasukan file yang ingin dikerjakan jika sudah tampil file tersebut, maka mahasiswa maupun pelajar memblok kata atau memasukkan keyword yang ingin di kutip lalu google scholar akan mencari kata keyword yang sesuai dengan perintah, dengan hitungan detik akan ditampilkankeyword yang dicari. Mahasiswa dan pelajar harus memilih kutipan yang paling sesuai dengan keyword tersebut dan jika sudah menemukan kutipan yang cocok sistem kutipan ini otomatis terkutip di google docs di dalam catatan kaki.

\subsection{Prototype}

Prototype adalah proses pembuatan model sederhana software yang mengijinkan pengguna memiliki gambaran dasar tentang program serta melakukan pengujian awal. Prototype memberikan fasilitas bagi pengembang dan pemakai untuk saling berinteraksi selama proses pembuatan, sehingga pengembang dapat dengan mudah memodelkan perangkat lunak yang akan di buat ${ }^{[5]}$. Pada prototype kutipan ini merupakan gambaran saat melakukan pengutipan yang otomatis tercantum di catatan kaki atau footnote di dalam google docs:

1. Buka Docs.google.com dan pastikan Email anda sudah tersambung di dalam google docs

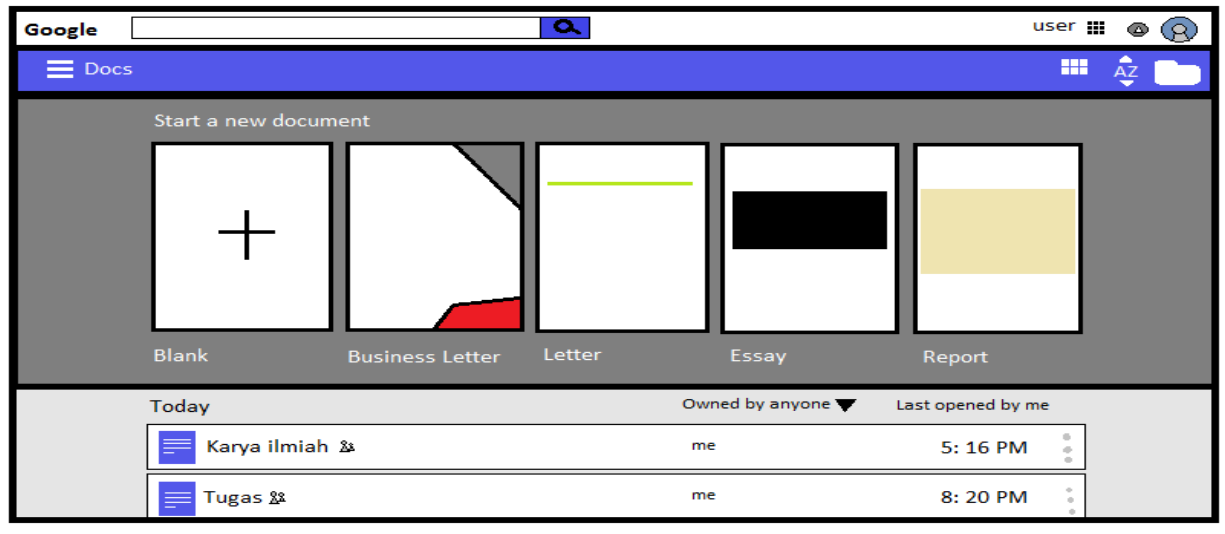

Gambar 5. <Prototype 1> Tampilan awal pada Google Docs

2. Bukafile yang ingin di kerjakan atau buat file baru

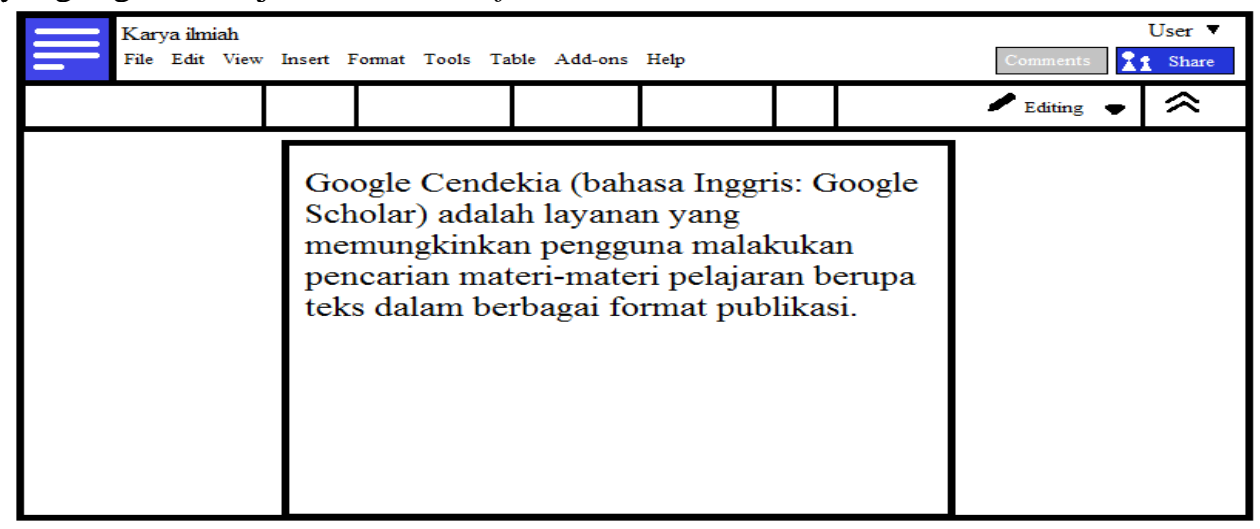

Gambar 6. <Prototype 2> Tampilan file dalam Google Docs

Di Google Docs dalam pengutipan mempunyai 3 cara yaitu : 
3.1 Blok kata atau kalimat yang ingin di kutip lalu klik kanan pada mouse klik Research

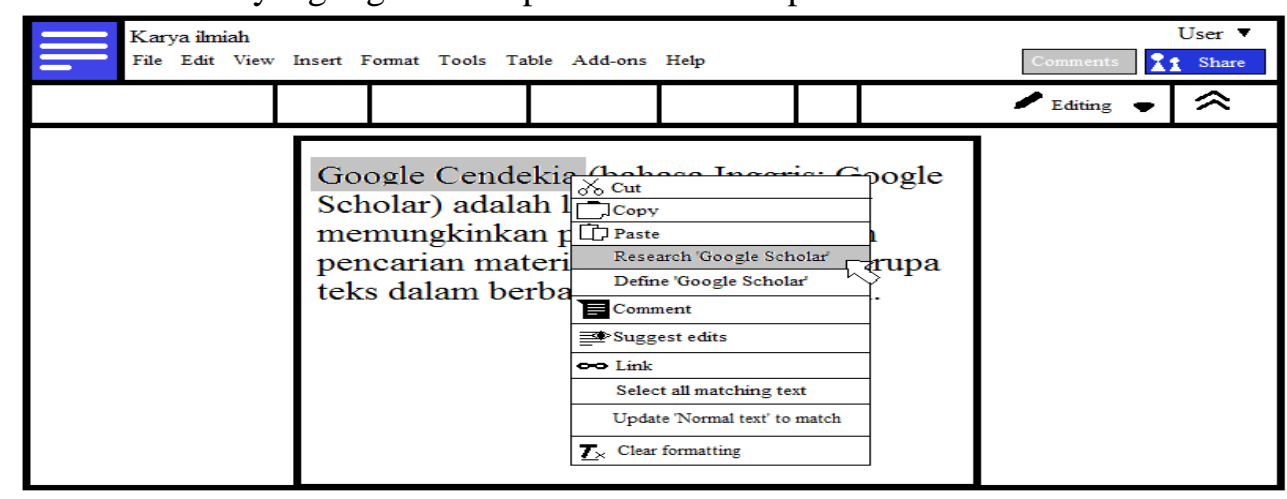

Gambar 7. <Prototype 3.1> Tampilan menu memilih klik kanan pada mouse

3.2 Blok kata atau kalimat yang ingin di kutip lalu klik Tools dan klik Research

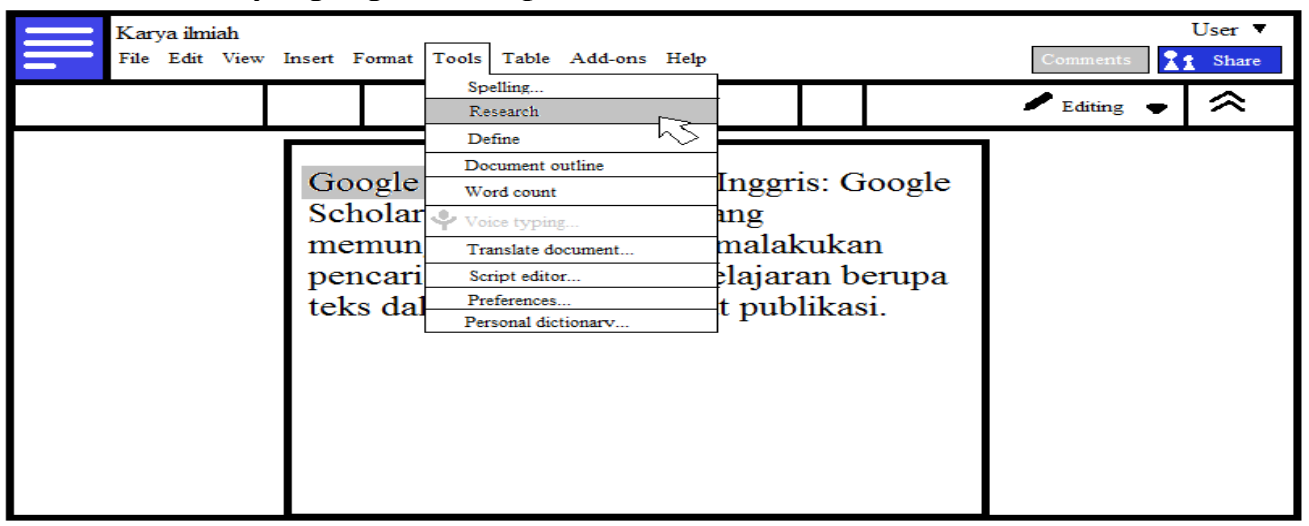

Gambar 8. <Prototype 3.2> Tampilan menu tools

3.3 Blok kata atau kalimat yang ingin di kutip lalu CTRL+ART+SHIFT+I

\begin{tabular}{|l|l|l|l|l|l|l|}
\hline Karya ilmiah \\
File Edit View Insert Format Tools Table Add-ons Help
\end{tabular}

Gambar 9. <Prototype 3.3> Tampilan cara dengan keyboard 
4. Tampilan selanjutnya akan tampil hasil pencarian lalu klik Cite as footnote

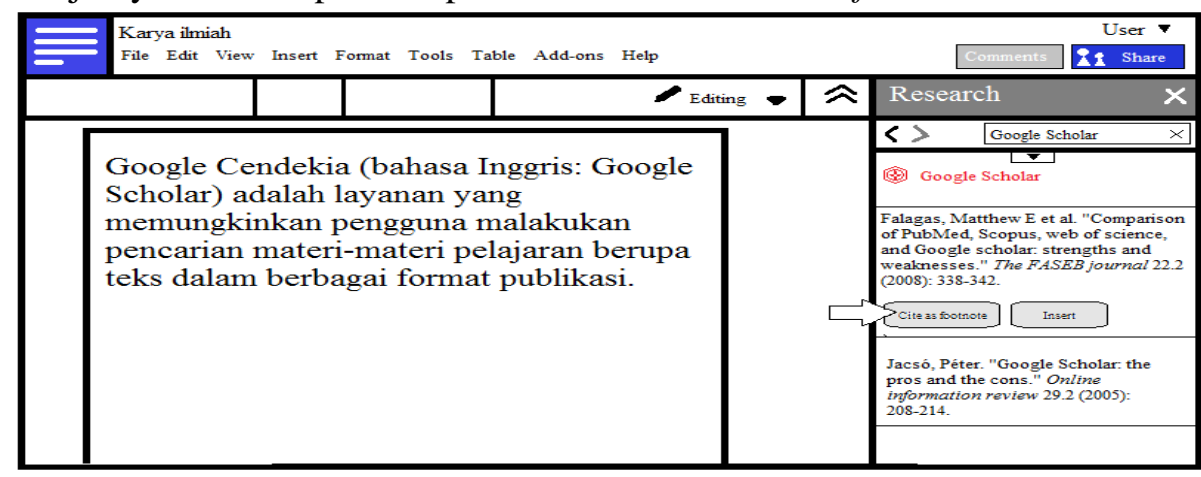

Gambar 10. <Prototype 4> Tampilan hasil pencarian

5. Tampilan kata atau kalimat yang sudah di kutip

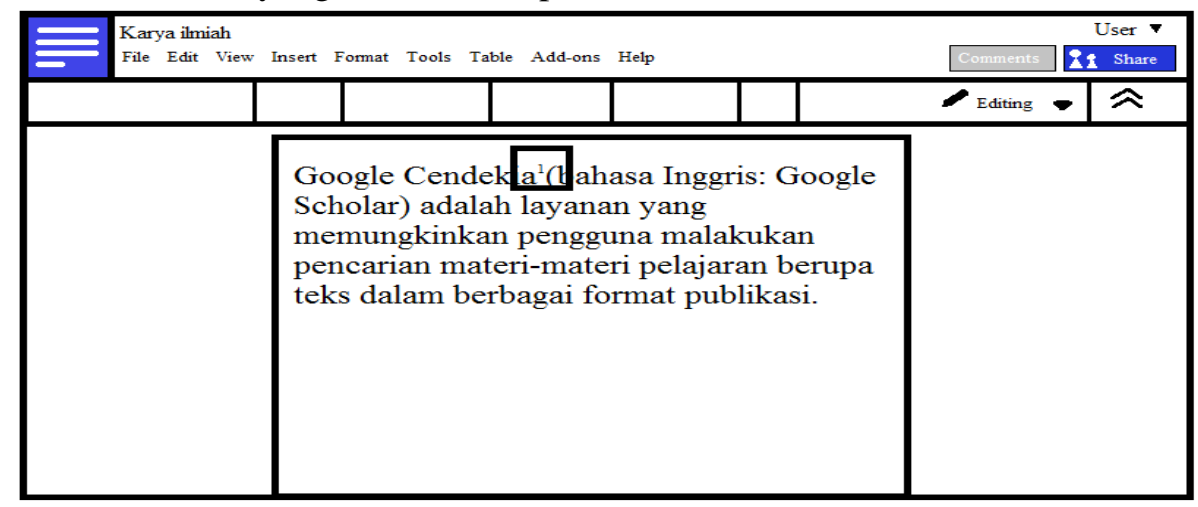

Gambar 11. <Prototype 5> Tampilan kutip

6. Tampilan kutipan di catatan kaki

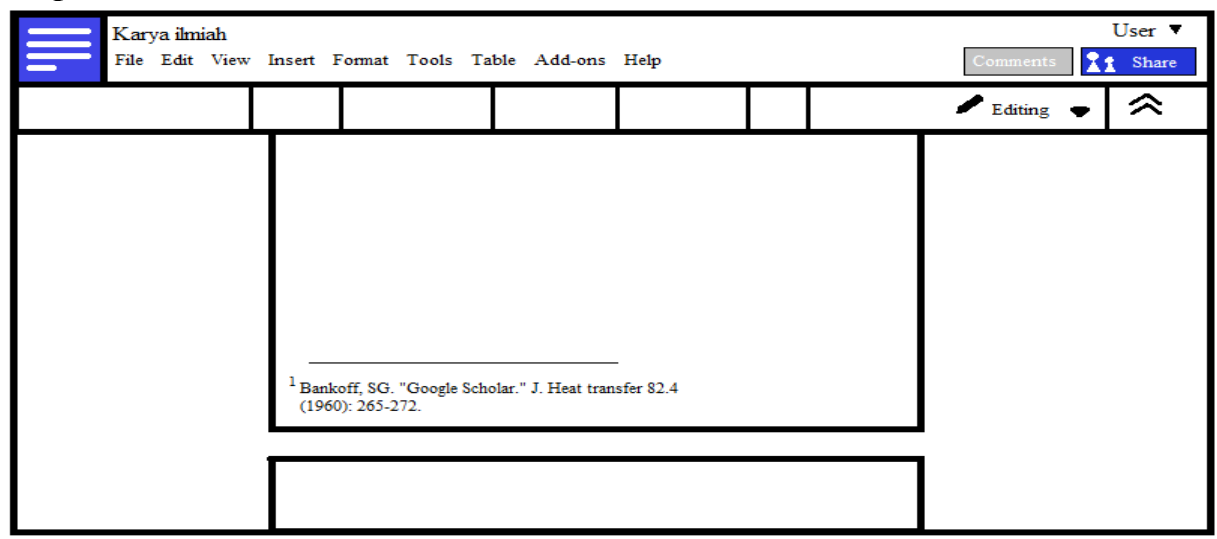

Gambar 12. <Prototype 6> Tampilan catatan kaki

\subsection{Implementasi}

Kutipan telah di implementasi kan pada sekolah-sekolah dan perguruan tinggi sebagai sarana mencari kutipan dalam pembuatan daftar pustaka dan catatan kaki yang efektif.

A. Tampilan hasil pencarian keyword di google scholar dalam google docs

Bagian ini sistem pencarian google scholar menggunakan kecepatan pencarian dengan hitungan detik langsung tampil apa yang mahasiswa dan pelajar cari. 


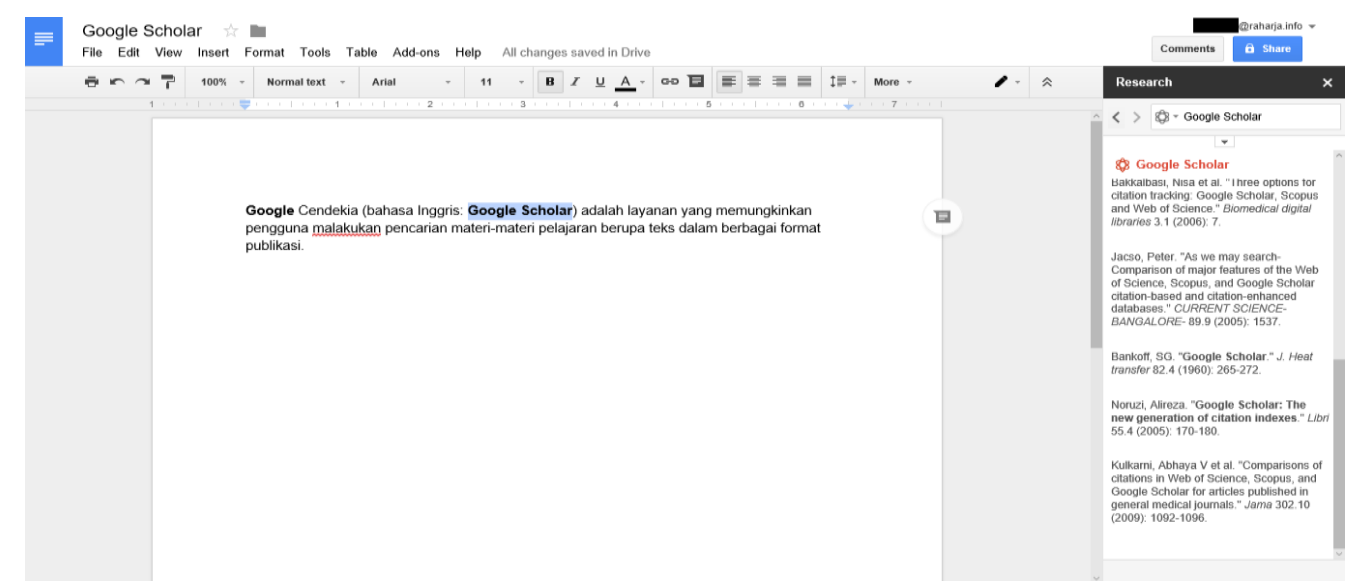

Gambar 13. Hasil pencarian Google scholar

B. Tampilan kutipan nomor

Di sini mahasiswa maupun pelajar bisa mengetahui dimana kutipan keyword yang tadi cari di google scholar dengan menggunakan Superscript nomor.

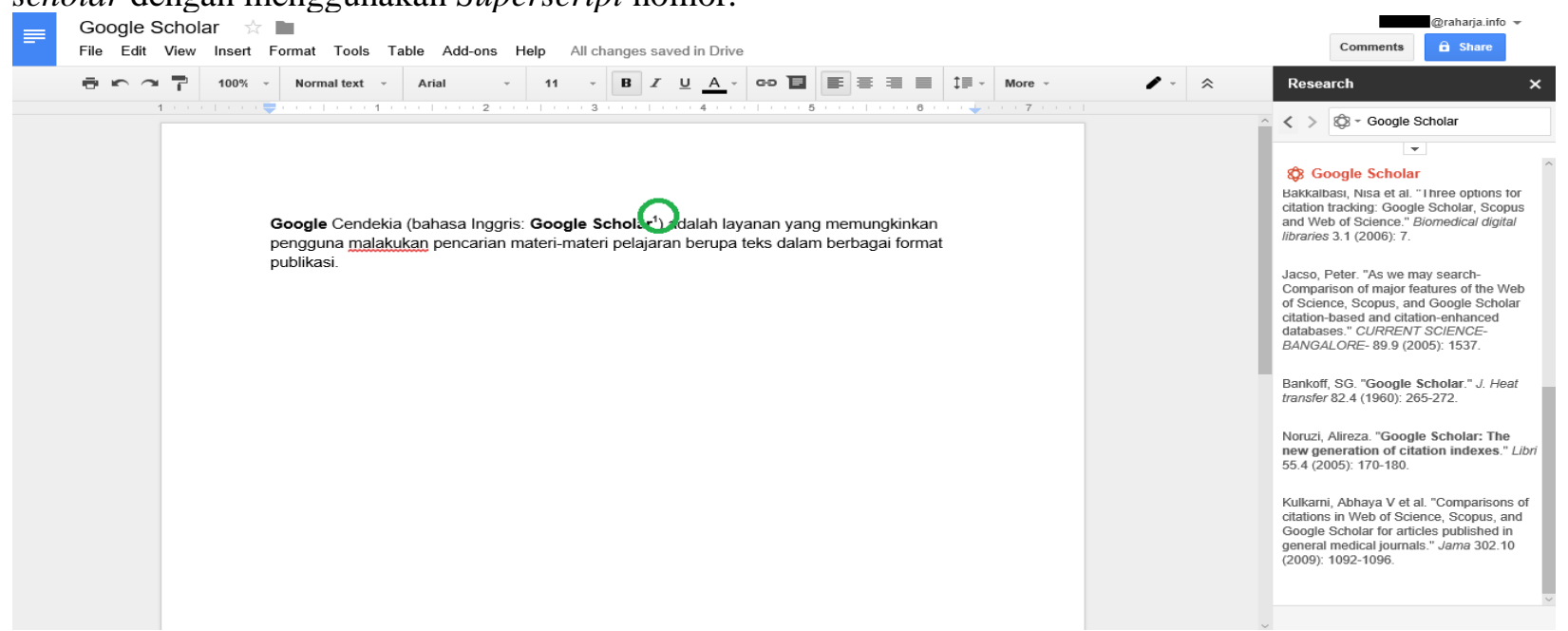

Gambar 14. Tampilan superscript nomor yang di tandai 


\section{.C. Tampilan penjelasan asal dari kutipan di catatan kaki}

Tampilan ini menjelaskan asal dari kutipan dengan menampilkan secara otomatis nama pembuat, judul, tahun, dan lain-lain di dalam catatan kaki.

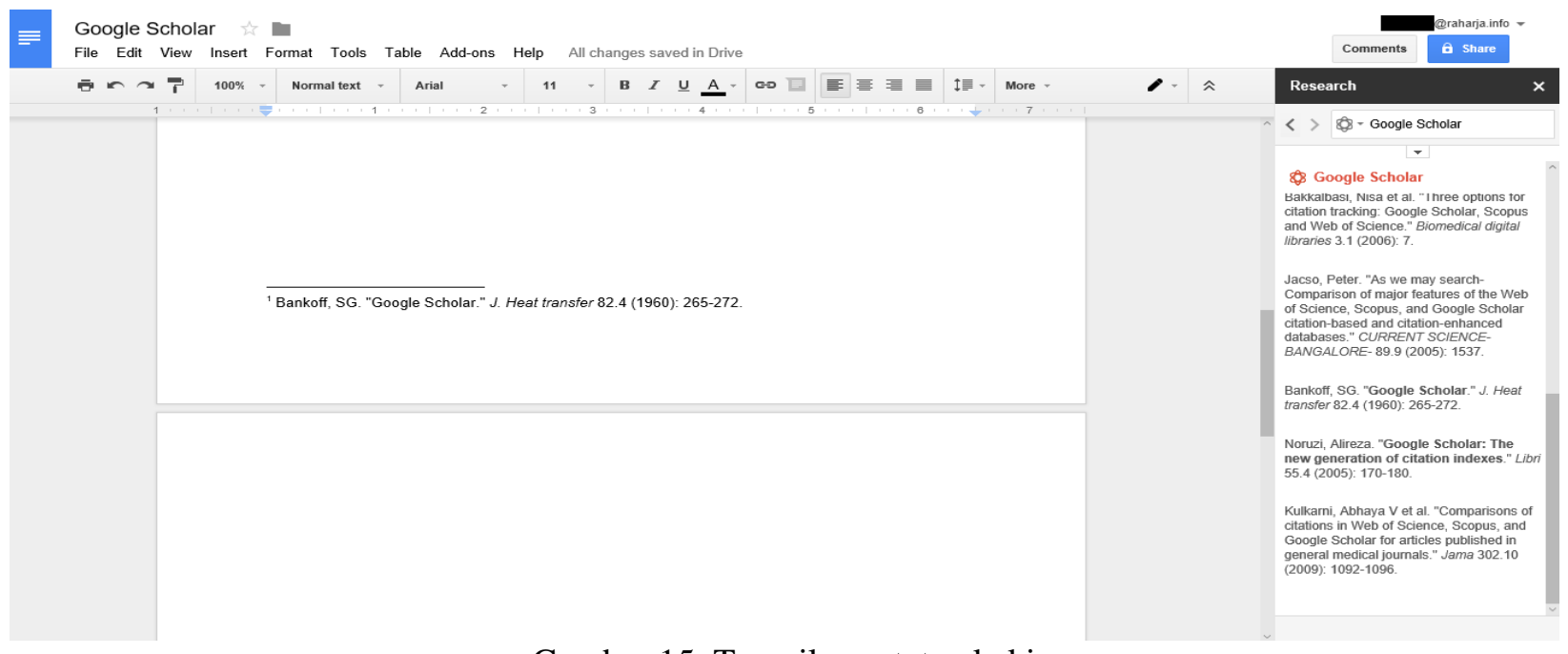

Gambar 15. Tampilan catatan kaki

\subsection{Kelebihan Kutipan}

Memudahkan mahasiswa dan pelajar dalam membuat kutipan ke dalam catatan kaki ataupun daftar pustaka di Google docs. Mahasiswa maupun pelajar tidak perlu lagi menulis dan mengubah kutipan yang ada dengan cara baru ini. Hanya dengan mencari di Google Scholarlalu di kutip otomatis langsung ada di catatan kaki.Mempercepat waktu dalam mengerjakan karya ilmiah di Google docs, dan tidak ribet lagi karena mahasiswa atau pelajar tidak perlu membuka website atau file-file yang ada di Google Scholar.Mahasiswa dan pelajar tidak perlu pusing karena di Google scholar ini menyediakan banyaknya kutipan-kutipan, kutipan-kutipan yang ada adalah kutipan orang-orang terpercaya dan orang-orang terkenal yang pastinya sangat membantu untuk membuat karya ilmiah para mahasiswa dan pelajar.

\subsection{Kelemahan Kutipan}

Masih di ragukan kebenaran kutipan tersebut karena ada banyaknya kutipan maka dari itu mahasiswa maupun pelajar harus memilih lagi kutipan-kutipan yang bermutu. Dalam mengerjakan kutipan tersebut secara otomatis hanya bisa di Google docs karena kutipan atau Citation ini masih berhubungan dengan Google. Dengan hanya bisa Google docs mahasiswa atau pelajar tidak bisa melakukan cara baru ini di Ms. Word ataupun aplikasi yang serupa.

\section{KESIMPULAN DAN SARAN}

Dengan demikian dapat disimpulkan, penelitian ini menggunakan metode studi pustaka. Sistem kutipan yang ada di google scholar ini lebih efektif dalam pembuatan daftar pustaka maupun catatan kaki di bandingkan dengan caracopy dan paste sebelumnya. Google scholar dengan kutipan-kutipan yang sangat banyak memudahkan mahasiswa maupun pelajar memilih kutipan yang bermutu, di tambah dengan otomatis nya terkutip di catatan kaki dalam google docs semakin mudah dan cepat mahasiswa dan pelajar dalam membuat catatan kaki atau daftar pustaka. Mahasiswa dan pelajar tidak perlu meng edit tanda atau kata-kata yang ada di daftar pustaka. Dengan adanya sistem kutipan ini diharapkan dapat memberikan kemudahan dalam melakukan penulisan catatan kaki ataupun daftar pustaka.Google scholar menyediakan fasilitas pencarian yang cepat dengan hitungan detik langsung ditampilkan, google scholar juga menyediakan mahasiswa maupun pelajar hasil penelitiannya disimpan di dalam google scholar.Free access adalah salah satu keunggulan dalam google scholar, dengan menggunakan Metode SWOT dapat 
meningkatkan sistem kutipan yang ada di google scholar ini, dan lebih banyak lagi yang tertarik dengan sistem otomatis kutipan yang ada di dalam google docs. Lebih dari 1000 universitas di dunia sudah menyimpan penelitiannya di google scholar. Menyediakan penelitian-penelitian berupa file PDF yang pastinya lebih lengkap dan bermutu. Dengan memperkenalkan dan mengajarkan google scholar pada mahasiswa dan pelajar diharapkan menjadi lebih tertarik dalam menggunakan sistem kutipan di google docs.

\section{DAFTAR PUSTAKA}

[1]. Dekeyser, Stijn, and Richard Watson. Extending google docs to collaborate on research papers. University of Southern Queensland, Australia 23 (2006): 2008.

[2]. Eyler, A.A., Dreisinger, M. Publishing on Policy: Trends in Public Health. Retrieved February 23, 2012 from http://www.cdc.gov/pcd/ issues/2011/jan/09_0247.htm.

[3]. Harzing, Anne-Wil, and Ron Van der Wal. Google Scholar: the democratization of citation analysis. Ethics in science and environmental politics 8.1 (2007): 61-73 Tiara, Khanna. Virtual Account.

[4]. Adelia, dan Jimmy Setiawan. 2011. Implementasi Customer Relationship Management (CRM) pada Sistem Reservasi Hotel berbasisi Website dan Desktop. Bandung: Universitas Kristen Maranatha. Vol. 6, No. 2, September 2011:113-126.

[5]. Aguillo, Isidro F. Is Google Scholar useful for bibliometrics?A webometric analysis. Scientometrics 91.2 (2011): 343-351.

[6]. Andriaty, Etty. Pemanfaatan jurnal elektronis dan kemutakhiran informasi yang disitir dalam publikasi primer. Jurnal Perpustakaan Pertanian 14.2 (2005): 25-31.

[7]. Bar-Ilan, Judit. Which h-index? - A comparison of WoS, Scopus and Google Scholar. Scientometrics 74.2 (2008): 257-271.

[8]. Beel, Jöran, Bela Gipp, and Erik Wilde. Academic Search Engine Optimization (aseo) Optimizing Scholarly Literature for Google Scholar \& Co. Journal of scholarly publishing 41.2 (2009): 176190.

[9]. Buzan, Tony. 2008. Buku Pintar Mind Map. Jakarta: PT. Gramedia Pustaka Utama.

[10]. Harzing, Anne-Wil, and Ron Van der Wal. Google Scholar: the democratization of citation analysis. Ethics in science and environmental politics 8.1 (2007): 61-73.

[11]. Hermawan.Asep. 2009. Penelitian Bisnis. Jakarta: Grasindo.

[12]. Jacsó, Péter. Google Scholar : the pros and the cons. Online information review 29.2 (2005): 208214.

[13]. Jacsó, Péter. Google scholar revisited. Online information review 32.1 (2008): 102-114.

[14]. Jogiyanto, 2005, Sistem Informasi Strategik untuk Keunggulan Kompetitif. Yogyakarta: Andi Offset.

[15]. Noruzi, Alireza. Google Scholar: The new generation of citation indexes. Libri 55.4 (2005): 170180.

[16]. William H. Walters. Google Scholar coverage of a multidisciplinary field. (2006).

[17]. "Pengertian, Fungsi dan Jenis Kutipan | lyta_manyunzz's Blog." 2015. 26 Apr. 2016. <https://lytasapi.wordpress.com/2010/06/05/pengertian-fungsi-dan-jenis-kutipan/> 